\title{
Evaluation of the High-Pressure Gas Transmission Network Impact for Environmental - Construction Phase and Network Operation
}

\author{
Urszula Kwast-Kotlarek', Maria Hełdak², Bartosz Jawecki ${ }^{3}$ \\ 1 Operator Gazociągów Przesyłowych GAZ-SYSTEM S.A. Oddział we Wrocławiu, Poland \\ 2 Wroclaw University of Environmental and Life Sciences, Department of Spatial Economy, Poland \\ 3 Wroclaw University of Environmental and Life Sciences, Institute of Landscape Architecture, Poland \\ * Corresponding author's e-mail: maria.heldak@upwr.edu.pl
}

\begin{abstract}
This thesis pertains to the influence of underground technical infrastructure during the construction phase on the selected components of the natural environment. The subject of research is the DN1000 MOP 8.4 MPa high pressure gas transmission system, realized in Poland from ZZU Wierzchowice till Kiełczów node. Studies identified the impacts on particular components of the environment, including land surface, plants, animals, biodiversity, air, water resources and quality, landscape and acoustic climate. An assessment was made on the impact, scale, frequency, duration or the influence type in the two stages of the investment process. It was found that the stage of DN1000 gas pipelines caused a significant change in the prevailing balance of the natural environment in the assembly area mainly due to soil transformation and vegetation removal as assessed as long-term. The impact on other components analysed in terms of frequency is usually medium-term or short-term, and in terms of duration momentary. During the operation of the gas pipeline, the negative impact of the network was strongly determined in relation to the forested areas and forests, where the negative impact was recorded not only during the implementation of the network but also in the phase of its use.
\end{abstract}

Keywords: pipeline, the impact of investment, assessment of impacts on the environment

\section{INTRODUCTION}

According to Shen L. et al. (2011), infrastructure projects have major effects on implementing the principles of sustainable development. Although the existing studies have suggested various methods to implement the sustainable development principles in infrastructure projects, effective assessment of sustainability and proper definition of its indicators are scarce in this industry in general (Hasheminasab et al., 2018).

Numerous researchers conducted gas pipeline quantitative risk assessments (Jo and Ahn, 2002; Joel and Duncan, 2003; Sklavounos and Rigas, 2006; Jo and Crowl, 2008; Jaffee, Suardina and Mcphate, 2009; Ma et. al., 2013). Currently, the quantitative risk assessment has become one of the important approaches for the risk management of gas pipeline network (Han and Weng, 2010).
In Poland, as a highly developed country, environmental impact assessment (EIA) is a key element of environmental management. Over a period of 40 years, the EIA has evolved and changed, driven by the changing needs of policymakers and the decision-making process, as well as the experience and ongoing practice (Morgan, 1998; 2012). Chi et al. (2016) stated that the environmental impact assessment (EIA) has been promoted as an instrument for preventive environmental management in construction projects, but its performance in safeguarding the environment through influencing the project decision-making is questioned.

The role Environmental Impact Assessment in the development process is recognised as an integral part of the planning and decision-making process. Its strength lies in its potential for analysing the associated environmental issues and 
for improving the siting, layout and design of particular scheme. The assessment of landscape and visual effects are an essential part of this process (Hełdak and Raszka 2011; Guidelines..., 2013, Jawecki, 2017). The current forecasting practice used in Poland, is based on the division of environmental components and on independent studies on effects carried out by different experts (Sas-Bojarska, 2007).

As reported in (Guidelines..., 2013), Environmental Impact Assessments (EIAs) were created in Great Britain, which cover a range of topics that could be summarised as covering the impacts on: human beings, population; flora and fauna; soil, water, air, climate; landscape; cultural heritage (including architectural and archeological heritage); material assets (Sas-Bojarska, 2007). Numerous studies pertaining to the evaluation of the area development level adopt indicators from the group of: urban land cover, or urban extent, are typically measured by the total built-up area (or impervious surface) of cities, Brueckner and Fansler (1983), Lowry (1988), Hasse and Lathrop (2003), Świąder et al. (2016). According to Han and Weng (2010), Ma et al. (2013) and Tokarczyk-Dorociak et al. (2019), decision-making regarding risk does not concern the technical aspects alone; rather, political, psychological, and societal processes all have a role to play.

This article presents a barely known problem of the gas pipelines DN1000 impact at two stages of the investment process: at the stage of construction and during the life of the gas pipeline. The aim of the study was to determine the effect of the impact of underground network execution for the selected component and the natural environment on an example of DN1000 MOP 8.4 MPa high-pressure pipeline section of ZZU Wierzchowice node Kiełczów. The investment was carried out under the construction of the gas pipeline border of Poland (Lasów) - TaczalinRadkowice-Gałów-Wierzchowice.

\section{MATERIALS AND METHODS}

The study included the area along the realized high pressure gas pipeline DN1000 MOP 8,4 MPa on route of polish border (Lasów) - Taczalin Radkowice - Gałów - Wierzchowice, on section from ZZU Wierzchowice till Kiełczów node near Wrocław. The entire route of the gas pipeline has a designated 12 meters of a controlled zone $(6 \mathrm{~m}$ from both sides of the gas pipeline axis), within which the gas network operator is entitled and will control all the gas pipeline safety activities. This area must be free of development.

The presented DN1000 gas pipeline is mostly built by open trench, only the intersections in the pipeline with terrain features such as roads, waterways, and the selected rivers, ponds on the route of the pipeline and in areas of natural value, will be laid trenchless. Longer cross joints and environmentally valuable areas have been made using trenchless horizontal directional drilling (HDD).

The impact assessment of technical infrastructure network implementation on the environment is presented in a tabular form, assessing the individual components of the environment during the implementation of the network and at the stage of its exploitation. The following scale was used in the study (Table 1).

1. Environmental impact assessments were conducted at two stages of the investment process: at the stage of construction and during the life of the gas pipeline. The work also assumes that the environmental requirements that need to be met during the pipeline construction work should include the following (Act on nature conservation, 2004; Rak, 2014):

2. Protection of the surface of the earth including soil and land relief - for that part of the site which, in accordance with the technical design, will be outside the area of earthworks.

3. Surface and groundwater protection - for the entire site.

4. Air protection against pollution - for the builtup areas.

5. Protection of the plant and animal world as well as urban greenery, including preservation of natural resources in the area outside the earthworks, restoration of these resources - in accordance with the design of green areas - in the area of earthworks but outside the roadways and cubature objects.

6. Environmental protection against noise and vibration - for the built-up areas.

7. Environmental protection against waste and other pollutants - for the entire site and neighbouring areas. 


\section{RESULTS AND DISCUSSION}

\section{Assessment of the impact of the high pressure gas network on the environment - construction phase}

According to the scale of assessment in Table 1, the impacts on particular components of the environment, including land areas, plants, animals, biodiversity, air, water resources and quality, landscape and acoustic climate. Assessment pertaining to the impact of implementing the gas network of high pressure on the environment at the stage of DN1000 MOP 8.4 MPa network construction on the section from ZZU Wierzchowice to the node of Kiełczów, is presented in Table 2.

The greatest impact on the soil is associated with the excavation. The effect of the humus shift is the destruction of soil levels, a change of the water-air conditions of the soil and the death of a large part of the less active animals. Increasing the oxygen access accelerates the mineralization of organic compounds and activates biogens. Soil fauna is one of the factors determining the fertility and biological productivity of soils. However, the biocoenosis of the "soil ecosystem" is rapidly renewing, so the effect on fertility is not long-lasting (here it is marked as medium term for meadows, wastes, woods and forests). Significant weight of humus heaps, equipment and vehicles contributes to the soil compaction. Increasing the soil concentration damages its structure and texture, reduces humidity and impedes the migration of oxygen. Compaction of the soil by kneading depends mainly on its moisture content. Excessive soil compaction reduces its water retention, promotes waterlogging, increases the risk of erosion due to leaching of water bodies to watercourses, reduces the nutrient uptake by plants, and weight of the root system. In case the surface is broken and the gas exchange is inhibited, the most pliable particles and low humus content are the most susceptible.

The possibility of temporary over-drying of the bedding (including selectively collected humus and forest litter), in addition to the flow of groundwater to the excavations and the need to lead them is noteworthy. These factors may have an influence on the temporary decrease of the biological activity of soil and, consequently, the temporary reduction of yield on agricultural land. The weight of the moving construction equipment, transport equipment and materials used
Table 1. Scale of impact assessment of a high pressure gas network construction on the environment

\begin{tabular}{|l|c|}
\hline \multicolumn{1}{|c|}{ Impact characteristic } & Description \\
\hline Nature of interactions & $\begin{array}{c}\text { direct (dir.) } \\
\text { indirect (indir) }\end{array}$ \\
\hline Scale & $\begin{array}{c}\text { negative (Neg) } \\
\text { positive (Pos) }\end{array}$ \\
\hline Frequency & $\begin{array}{c}\text { short-term (S-t) } \\
\text { medium-term (M-t) } \\
\text { long-term (L-t) }\end{array}$ \\
\hline Time duration & $\begin{array}{c}\text { momentary (Mom) } \\
\text { constant (con) }\end{array}$ \\
\hline $\begin{array}{l}\text { No impact or irrelevant } \\
\text { impact }\end{array}$ & \begin{tabular}{c} 
negligible influence (Ni) \\
\hline $\begin{array}{l}\text { Potential impact difficult to } \\
\text { estimate, or impact can be } \\
\text { both positive and negative }\end{array}$
\end{tabular} \\
\hline
\end{tabular}

for the construction of the gas pipeline (mainly pipes) can lead to soil compaction, which results in the destruction of its structure. In arable land, it can also lead to a deterioration of the soil structure and a decrease in its biological activity.

The construction of the gas pipeline requires the removal of vegetation from the whole area for the works. Due to the linear character of the investment, this area is a strip of length equal to the length of the gas pipeline and its width depending on its diameter - the width of the mounting area was about $33 \mathrm{~m}$ (Environmental impact report..., 2014). Vegetation outside this area should not have been affected by the construction. The situation where a pipeline in the ground interferes with the migration of groundwater may be an exception. In this case, the vegetation outside the assembly belt may be weakened or the composition of the community may be reduced. During the construction work, the deeper layers of the earth may be formed within the mounting belt. In such places, hypoxia in heavy soils and excessive mechanical resistance to medium and light constitute the limiting factor for plant yield.

At the construction stage, excavations that are anthropogenic traps usually have an impact on small animal species. It was rated as Direct (Dir), Negative (Neg), and Medium-term (M-t). The danger is mainly in amphibians and reptiles in migration periods. Due to the fact that all national species of amphibians and reptiles are protected in Poland and in relation to them according to $\S 6 \mathrm{sec} .1 \mathrm{pt} .12)$ Ordinance of the Minister of the Environment of 6 October 2014 on the protection of species of animals (2014), a ban of intentional movement from regular attendance place to 
Table 2. Assessment of the impact of implementing the high pressure gas network on the environment during the network construction phase

\begin{tabular}{|c|c|c|c|c|c|c|}
\hline \multirow[b]{2}{*}{ Index } & \multirow[b]{2}{*}{$\begin{array}{l}\text { Environmental } \\
\text { components: }\end{array}$} & \multicolumn{5}{|c|}{ Current way of development: } \\
\hline & & $\begin{array}{c}\text { Rural development } \\
\text { areas }\end{array}$ & $\begin{array}{c}\text { Ararable land, } \\
\text { Meadow, } \\
\text { pasture }\end{array}$ & Barren & Forresting & Forrests \\
\hline 1. & Earth surface & $\begin{array}{l}\text { Dir } \\
\text { Neg } \\
M-t\end{array}$ & $\begin{array}{c}\text { Dir } \\
\text { Neg } \\
\text { M-t }\end{array}$ & $\begin{array}{c}\text { Dir } \\
\text { Neg } \\
\text { M-t }\end{array}$ & $\begin{array}{c}\text { Dir } \\
\text { Neg } \\
\text { M-t }\end{array}$ & $\begin{array}{c}\text { Dir } \\
\text { Neg } \\
\text { M-t }\end{array}$ \\
\hline 2. & Flora & $\begin{array}{l}\text { Dir } \\
\text { Neg } \\
\text { M-t }\end{array}$ & $\begin{array}{c}\text { Dir } \\
\text { Neg } \\
\text { M-t }\end{array}$ & $\begin{array}{l}\text { Dir } \\
\text { Neg } \\
\text { M-t }\end{array}$ & $\begin{array}{c}\text { Dir } \\
\text { Neg } \\
\text { L-t }\end{array}$ & $\begin{array}{c}\text { Dir } \\
\text { Neg } \\
\text { L-t }\end{array}$ \\
\hline 3. & Fauna & $\mathrm{Ni}$ & $\begin{array}{l}\text { Dir } \\
\text { Neg } \\
\text { M-t }\end{array}$ & $\begin{array}{l}\text { Dir } \\
\text { Neg } \\
\text { M-t }\end{array}$ & $\begin{array}{c}\text { Dir } \\
\text { Neg } \\
\text { L-t }\end{array}$ & $\begin{array}{c}\text { Dir } \\
\text { Neg } \\
\text { L-t }\end{array}$ \\
\hline 4. & Biological diversity & $\mathrm{Ni}$ & $\begin{array}{c}\text { Dir } \\
\text { Neg } \\
\text { M-t }\end{array}$ & $\begin{array}{c}\text { Dir } \\
\text { Neg } \\
\text { M-t }\end{array}$ & $\begin{array}{c}\text { Dir } \\
\text { Neg } \\
\text { L-t }\end{array}$ & $\begin{array}{c}\text { Dir } \\
\text { Neg } \\
\text { L-t }\end{array}$ \\
\hline 5. & Air & $\mathrm{Ni}$ & $\begin{array}{c}\text { Dir } \\
\text { Neg } \\
\text { M-t }\end{array}$ & $\begin{array}{c}\text { Dir } \\
\text { Neg } \\
\text { M-t }\end{array}$ & $\begin{array}{c}\text { Dir } \\
\text { Neg } \\
\text { M-t }\end{array}$ & $\begin{array}{c}\text { Dir } \\
\text { Neg } \\
\text { M-t }\end{array}$ \\
\hline 6. & $\begin{array}{l}\text { Resources and quality of } \\
\text { surface waters }\end{array}$ & $\begin{array}{c}\text { Indir } \\
\text { Neg } \\
\text { M-t }\end{array}$ & $\begin{array}{c}\text { Indir } \\
\text { Neg } \\
\text { M-t }\end{array}$ & $\begin{array}{c}\text { Indir } \\
\text { Neg } \\
\text { M-t }\end{array}$ & $\begin{array}{l}\text { Indir } \\
\text { Neg } \\
\text { M-t }\end{array}$ & $\begin{array}{c}\text { Indir } \\
\text { Neg } \\
\text { M-t }\end{array}$ \\
\hline 7. & $\begin{array}{l}\text { Resources and quality of } \\
\text { underwaters }\end{array}$ & $\mathrm{Ni}$ & Indir & Indir & Indir & Indir \\
\hline 8. & Landscape & $\mathrm{Ni}$ & $\begin{array}{c}\text { Dir } \\
\text { Neg } \\
\text { S-t }\end{array}$ & $\begin{array}{c}\text { Dir } \\
\text { Neg } \\
\text { S-t }\end{array}$ & $\begin{array}{c}\text { Dir } \\
\text { Neg } \\
\text { L-t }\end{array}$ & $\begin{array}{c}\text { Dir } \\
\text { Neg } \\
\text { L-t }\end{array}$ \\
\hline 9. & Climate & $\mathrm{Ni}$ & Indir & Indir & Indir & Indir \\
\hline 10. & Acoustic climate & $\begin{array}{c}\text { Dir } \\
\text { Neg } \\
\text { Mom }\end{array}$ & $\begin{array}{c}\text { Dir } \\
\text { Neg } \\
\text { Mom }\end{array}$ & $\begin{array}{l}\text { Dir } \\
\text { Neg } \\
\text { Mom }\end{array}$ & $\begin{array}{c}\text { Dir } \\
\text { Neg } \\
\text { Mom }\end{array}$ & $\begin{array}{c}\text { Dir } \\
\text { Neg } \\
\text { Mom }\end{array}$ \\
\hline 11. & Natural resources & $x$ & $x$ & $x$ & $\mathrm{Ni}$ & $\mathrm{Ni}$ \\
\hline 12. & Monuments & $x$ & $x$ & $x$ & $\mathrm{Ni}$ & $\mathrm{Ni}$ \\
\hline 13. & Martial goods & $x$ & $x$ & $x$ & $\mathrm{Ni}$ & $\mathrm{Ni}$ \\
\hline
\end{tabular}

Explanation of the indications used in the table: nature of the interaction: Dir - direct , Indir - indirect; scale: Neg - negative, Pos - positive; Frequency: S-t - Short term, M-t Medium - Term, L-t - Long term; duration: Mom - momentary, Con - constant; Ni - no impact or irrelevant effect; $\mathrm{X}$ - Potential impact difficult to estimate, or impact can be both positive and negative..

another is in force - it is needed to achieve permission for derogation from the ban.

The noise of construction machines and the presence of people scare animals (Rak, 2014). More sensitive species of mammals and birds may leave the area in the vicinity of work. Reproduction, abandonment of chicks or eggs may occur as well. The greatest damage is associated with the mating and resting of migratory birds. As a result of the removal of vegetation and the humus layer, a large proportion of the less active animals are killed.

During the construction work, there may be atmospheric pollution caused by unorganized emissions, mainly related to the work of assembly equipment and means of transport driven by combustion engines emitting e gaseous pollutants as well as welding gases formed during welding of pipes into the atmospher. During construction, the aerosanic condition of the air decreases the exhaust gases of machines and vehicles. As a result of earthworks, dusting of the earth's material can occur by pouring waterways (Engel, 2001). The air nuisance was assessed as negative (Neg), and given the often protracted construction process, with respect to the duration of the nuisance as a medium term (M-t). The use of steel plates allows to minimize the dust emissions to 
the atmosphere as a result of moving equipment after construction. The situation is particularly drought-stricken (Figure 1).

With regard to surface waters, it has been established that when crossing the watercourses, the bottom sediments are broken, resulting in the increase of debris in the aquatic ecosystem. This is accompanied by the destruction of benthic organisms and the formation of slurry, which significantly deteriorates the background and physicochemical parameters of water. Contamination spreads down the streams at considerable distances, and in ponds and rivers it may cause long-standing maintenance of excess water quality parameters, in violation of the conditions of water fauna. In standing water, these changes cause long-term effects, because the water-selfcleaning processes are weaker there than in the flowing waters. The water demand is limited only to the implementation stage and is related to the need to provide water for the social and welfare purposes for employees and the water necessary for technological processes - surface water intake for gas pressure testing and for drilling purposes.

The water used for the hydraulic testing will be a temporary water intake. In the case of not being able to take water from a natural stream (e.g. river Sąsiecznica, Głęboki Rów), water can be collected from local waterworks and then transported to a test site or pumped from another pipeline after a leak test. The collected water will be discharged to the environment after the end of the test, with the discharge location being different from the collection site. The water intake from natural watercourses does not exceed the amount of water needed to maintain the flow of unproductive watercourses and should not cause changes in the water quality. The discharge of water after the test is carried out through the settling tanks to the receiver after obtaining the consent of the competent management authority under the conditions indicated in the water permit for the specific use of the water. The water intake for hydrostatic testing takes place outside of low water. While removing water into the receiver, the hydrostatic force is adjusted so that the water level fluctuations and physicochemical changes are minimized - the spraying method is applied. The water discharge after sampling is only quantitative, i.e. no changes in the chemical properties of the water are taken during the work. This means that water is supplied to the receiver with a chemical composition identical to that of the water taken from the aquifer. Therefore, the planned work does not affect the change of hydrogeochemical relations and chemical composition within receiver waters.

In the areas with high groundwater level, drainage of excavations is performed (Figure 2). In the sections where the bottom of the trench is below the groundwater level, it is anticipated that the water will be pumped directly from the trench. In order to facilitate the pumping of water, drainage is made in well-permeable soils (gravels, thick sands, bedbugs). At the lowest points of the excavation there are wells of

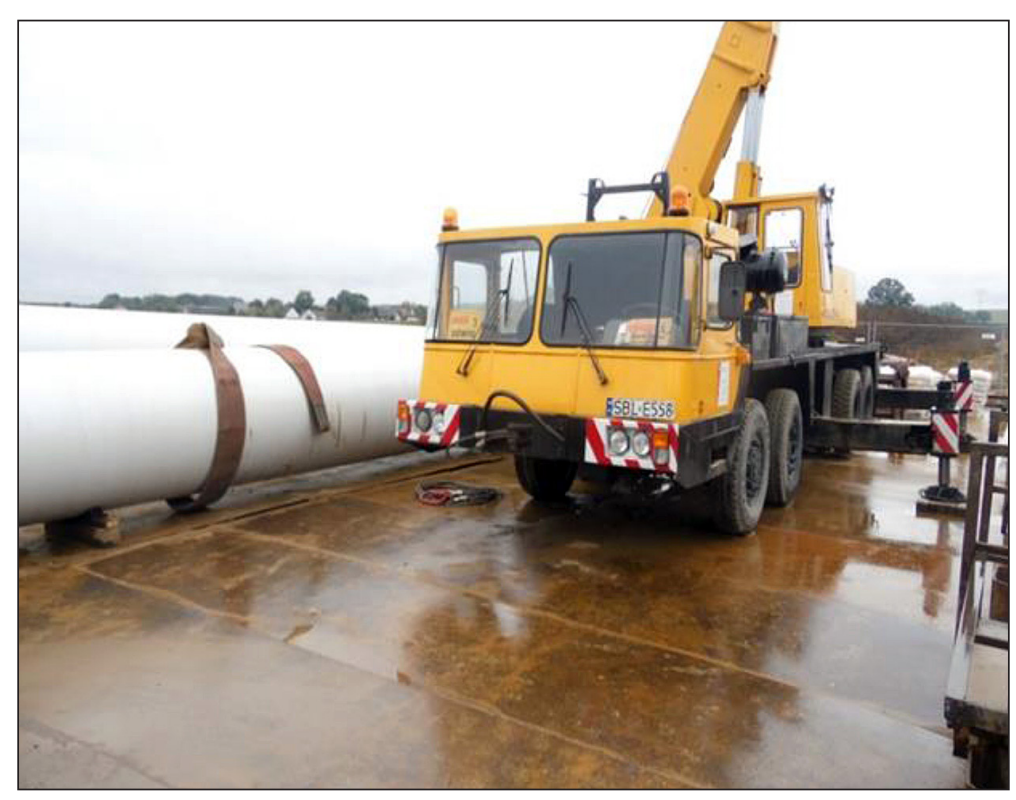

Figure 1. Application of steel plates at the construction stage 


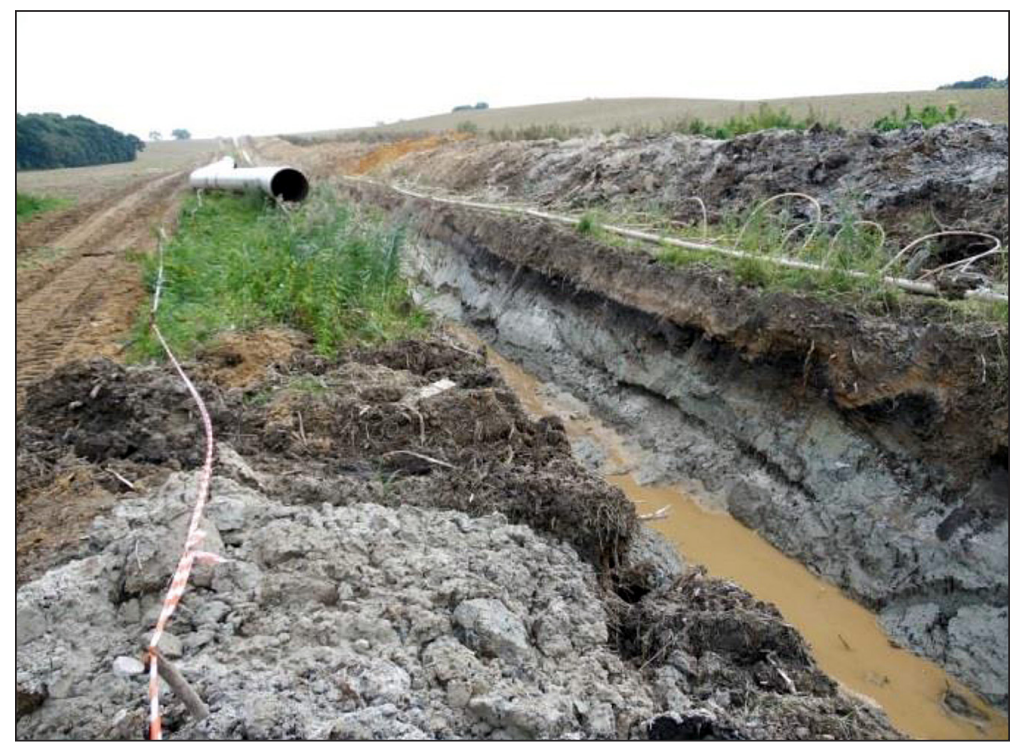

Figure 2. Ground water level and dehydration

concrete rings with a diameter of $0.6 \mathrm{~m}$ and a depth of $1.0 \mathrm{~m}$, or drainage grooves or drainage tapes. In the case of low permeability soils, the needle pumping is not effective in pumping water from the excavation. Dewatering is carried out until laying and covering the gas pipeline. Before beginning to fill up the excavations in the wetlands, the pipeline is loaded with concrete saddle weights to prevent the pipeline from being displaced by ground water.

Fluids may leak during operation. The sensitivity of groundwater to such impurities depends on the depth of the aquifers, the adsorption capacity of the soil cover as well as the amount and type of impurities. Shallow groundwater that is associated with sandy soils is the most susceptible to pollution.

The areas adjacent to the gas pipeline are affected by indirect impacts of significantly less power. Therefore, during fieldwork the ground cover was compared in the anthropogenic zone of the mounting area and in its immediate vicinity (about 250 outside the mounting area). The variation was in the category of coverage in the gas pipeline in relation to its surroundings and the occurrence of these changes was compared with the nature of the soils and with the occurrence of the first level of groundwater. In the vicinity of the assembly area there are usually arable land, tilled areas and tree and shrub areas. In most sections of the zone, the coverage area is the same as in the adjacent areas. Certain structural and functional changes have occurred, for example, of granulometric composition and soil structure, but not large enough to lead to a change in the land cover category. The estuarine and pruned areas are the least resistant to the disturbances caused by the construction of the gas pipeline. The most resistant areas were built up (their reproduction did not depend on the characteristics of the environment), the mixed category (narrow stripes of stripped land and arable land) and surface water.

The analysis of the co-occurrence of land cover changes and the observed environmental features showed the greatest dependence on the land taken and least to the low vegetation. Among the various soil types used in the analysis of soil conditions, soil types were the least correlated with the occurrence of the land cover changes. There is only a weak dependence between the complexes of agricultural suitability and the type of soil and the occurrence of changes. The greatest resistance is shown by the soils of the weak cereal-fodder complex and soils belonging to the extreme soil types, i.e. light and heavy soil. Among the analysed features of the environment, the greatest dependence was observed between the occurrence of land cover changes and the granulometric composition of soil substrates and surface works. No change is characteristic of the land located on the clay, and the least resistant are the total soils made of aluminum. Ther is a very clear dependence of land cover changes on the depth of the groundwater table - the semi-plant vegetation is quickly" recreated. 


\section{Evaluation of the acoustic conditions in the environment of the planned undertaking}

The vast majority of the areas surrounding the pipeline are undeveloped areas, including agricultural land, wasteland, forests and ponds. The remaining sections are residential buildings composed of single buildings, rarely of a dozen buildings. The investment is related to temporary noise nuisances mainly occurring during its construction (Engel, 2001). The magnitude of these nuisances is mainly influenced by the simultaneous operation of multiple machines and equipment (e.g. excavators, bulldozers, drilling rigs, drilling mudguards, scrubbing pump, welding aggregate, wheeled tractor, generator) on a relatively small area and time investment process. These burdens will take place over a period of several weeks, supportive and preparatory work and the vast majority of construction work will be done with noise-generating equipment. The noise and vibration emissions will be closely related to the moving front of building and assembly works. In the case of the trenching methods, the impact will disappear in the evening, with trenchless methods going around the clock. Due to the short time of occurrence, it will not cause permanent negative changes in the environment.

The investments related to the considered underground infrastructure with the gas pipeline cause a temporary occupation of the space (for the construction period) and violation of the existing state of use and management. The property after completion of construction returns to the owner and further use (usually primary). Restoration of usefulness to such degraded soils takes place through land reclamation.

As a result of line investments, users and owners of real estate located in the construction lane will be subject to certain damages, the size and range of which depend on:

- forms of land occupation (permanent, temporary)

- current state of land development,

- the current function,

- site location for the linear investment route,

- the diligence of the construction work,

- correctness of the performed reclamation works.

The specificity of land reclamation is disturbed by the nature of the remediation object. It is characterized by a linear character - it is a narrow and elongated strip of land. Realization of the gas pipeline imposes a reclamation work on the operator, i.e. creating the best conditions for, for example, agricultural production and the creation of similar conditions (identical to those in the vicinity of the area occupied by the infrastructure). Therefore, it is unfortunate to recognize the possibility of creating an area with better or worse production values, as a result of reclamation.

\section{Assessment of the impact of the gas network of high pressure on the environment - the stage of exploitation}

Evaluation pertaining to the impact of the implementation of the high pressure gas network DN1000 MOP 8.4 MPa on the section from ZZU Wierzchowice to the Kiełczów node, on the environment at the stage of network operation is set out in table 3 .

Once completed, the vegetation is reintroduced in the mounting area. In the long-term run, the vast majority of communities that have been negatively impacted should be able to renew and regain their lost functions. The only exception is the foliage, which cannot be introduced in the socalled controlled area dependent on, among others from the operating pressure of the medium, the diameter of the gas pipeline. The winds of the "corridor" blow with a great power, damaging some trees on the edge, which are not adapted to exist outside the compact forest complex. The table above shows the direct impact of the gas pipeline on the forest vegetation and on the trees (Dir., Neg, L-t, Con).

The trees in the newly created forest wall are also not accustomed to high sunshine; therefore, they are subject to light and thermal shock (Suchocka and Milanowska, 2015). The weakening of their viability is most often attributed to thinning of the crown, premature yellowing and falling of leaves or needles, branching of branches, and even trees of trees. The effect of the described changes is comparable to the response of the trees after the normal decay, so it can be assumed that their cause is not due to deformation of the water levels caused by the drainage of the water through the linear infrastructure. In a glade, grasslands are usually formed in habitats, with a high proportion of less demanding weeds, which consolidate the soil and enrich it with organic matter. On the other hand, fresh weeds are generally predominant. 
Table 3. Assessment of the impact of the operation of the high pressure gas network on the environment during its use

\begin{tabular}{|c|c|c|c|c|c|c|}
\hline \multirow[b]{2}{*}{ Index } & \multirow[b]{2}{*}{ Environmental components: } & \multicolumn{5}{|c|}{ Current way of development: } \\
\hline & & $\begin{array}{c}\text { Rural development } \\
\text { areas }\end{array}$ & $\begin{array}{c}\text { Ararable land, } \\
\text { Meadow, } \\
\text { pasture }\end{array}$ & Barren & Forresting & Forrests \\
\hline 1. & Earth surface & Dir & Dir & Dir & Dir & Dir \\
\hline 2. & Flora & Indir & Indir & Indir & $\begin{array}{l}\text { Dir } \\
\text { Neg } \\
\text { L-t } \\
\text { Con }\end{array}$ & $\begin{array}{l}\text { Dir } \\
\text { Neg } \\
\text { L-t } \\
\text { Con }\end{array}$ \\
\hline 3. & Fauna & $\mathrm{Ni}$ & $\mathrm{Ni}$ & $\mathrm{Ni}$ & $\begin{array}{c}\text { Dir } \\
\text { Neg } \\
\text { L-t }\end{array}$ & $\begin{array}{c}\text { Dir } \\
\text { Neg } \\
\text { L-t }\end{array}$ \\
\hline 4. & Biological diversity & $\mathrm{Ni}$ & $\mathrm{Ni}$ & $\mathrm{Ni}$ & $\begin{array}{c}\text { Dir } \\
\text { Neg } \\
\text { L-t }\end{array}$ & $\begin{array}{c}\text { Dir } \\
\text { Neg } \\
\text { L-t }\end{array}$ \\
\hline 5. & Air & $\mathrm{Ni}$ & $\mathrm{Ni}$ & $\mathrm{Ni}$ & $\mathrm{Ni}$ & $\mathrm{Ni}$ \\
\hline 6. & $\begin{array}{l}\text { Resources and quality of } \\
\text { surface waters }\end{array}$ & $\mathrm{Ni}$ & $\mathrm{Ni}$ & $\mathrm{Ni}$ & $\mathrm{Ni}$ & $\mathrm{Ni}$ \\
\hline 7. & $\begin{array}{l}\text { Resources and quality of } \\
\text { underwaters }\end{array}$ & $\mathrm{Ni}$ & $\mathrm{Ni}$ & $\mathrm{Ni}$ & $\mathrm{Ni}$ & $\mathrm{Ni}$ \\
\hline 8. & Landscape & $\mathrm{Ni}$ & $\mathrm{Ni}$ & $\mathrm{Ni}$ & $\begin{array}{c}\text { Dir } \\
\text { Neg } \\
\text { L-t } \\
\text { Con }\end{array}$ & $\begin{array}{l}\text { Dir } \\
\text { Neg } \\
\text { L-t } \\
\text { Con }\end{array}$ \\
\hline 9. & Climate & $x$ & $x$ & $x$ & $\begin{array}{c}\text { Indir } \\
\text { Neg } \\
\text { L-t }\end{array}$ & $\begin{array}{c}\text { Indir } \\
\text { Neg } \\
\text { L-t }\end{array}$ \\
\hline 10. & Acoustic climate & $x$ & $x$ & $x$ & $x$ & $x$ \\
\hline 11. & Natural resources & $x$ & $x$ & $x$ & $x$ & $x$ \\
\hline 12. & monuments & $x$ & $x$ & $x$ & $x$ & $x$ \\
\hline 13. & Martial goods & $\begin{array}{l}\text { Dir } \\
\text { Neg } \\
\text { L-t } \\
\text { Con }\end{array}$ & $\begin{array}{c}\text { Dir } \\
\text { Neg } \\
\text { L-t } \\
\text { Con }\end{array}$ & $\begin{array}{c}\text { Dir } \\
\text { Neg } \\
\text { L-t } \\
\text { Con }\end{array}$ & $\begin{array}{l}\text { Dir } \\
\text { Neg } \\
\text { L-t } \\
\text { Con }\end{array}$ & $\begin{array}{c}\text { Dir } \\
\text { Neg } \\
\text { L-t } \\
\text { Con }\end{array}$ \\
\hline
\end{tabular}

Explanation of the indications used in the table: nature of the interaction: Dir - direct, Indir - indirect; scale: Neg - negative, Pos - positive; Frequency: S-t - Short term, M-t - Medium Term, L-t - Long term; duration: Mom - momentary, Con - constant; Ni - no impact or irrelevant effect; X - Potential impact difficult to estimate, or impact can be both positive and negative.

At the end of the work, measures are being taken to bring the crop yields to the pre-construction state. However, a slight decrease in the crop yield may last for several years after completion of the work. The cause of deterioration of soil fertility is the disturbance of its structure and composition during the construction work (Maziarek and Krawczyk, 2015).

During the operation of the pipeline, negative impacts on particular groups of animals depend on their environmental requirements, response to disturbances and the degree of biotope disruption. The indirect effects are caused, for example, by limiting the possibility of finding refuge or free migration. Hence, the negative impact of the gas pipeline on animal and plant dawn in forested and wooded areas (Dir., Neg. L-t, Con).

At the stage of operation, the gas pipeline will most likely have little impact on the countryside. Several years after the end of the reclamation, the route should not be visible on the ground, since the cover of the soil layer allows vegetation to develop. The only elements that interfere with the landscape will be cubature objects (e.g. barriers, etc.), passage through wooded areas, and in the case of gas pipelines also yellow markers. In forest areas, the ban on the introduction of soils in the so-called controlled area has a significant negative impact on the landscape. It results in the creation of a non-forested corridor, which was 
included in the assessment of the impact of the gas pipeline on the landscape (Figure 3 and 4).

Implementation of the gas pipeline limits the possibility of developing the property in the course of network operation. The pipeline process changes the existing spatial structure and the existing production systems. Introducing a controlled area permanently lowers the capacity of the forest, but primarily limits the freedom of the owner or user of the property. Hence, in the accepted assessment of the impact of the gas network on material goods, the negative impact of the gas pipeline has occurred (Dir., Neg, L-t, Con)
The existence of the gas pipeline probably does not affect the weather and Mesozoic processes in any way. Its implementation affects the microclimate only in the forest areas. At the stage of construction, all vegetation is removed, and during operation in the so-called control zone cannot include trees. Permanent removal of trees results in a change in the air circulation associated with the increased flow of the existing glade (Mazur, 2004), because the presence of trees affects the change of wind direction and speed (Madungwe and Mukonzvi, 2012; Jawecki et al., 2019).

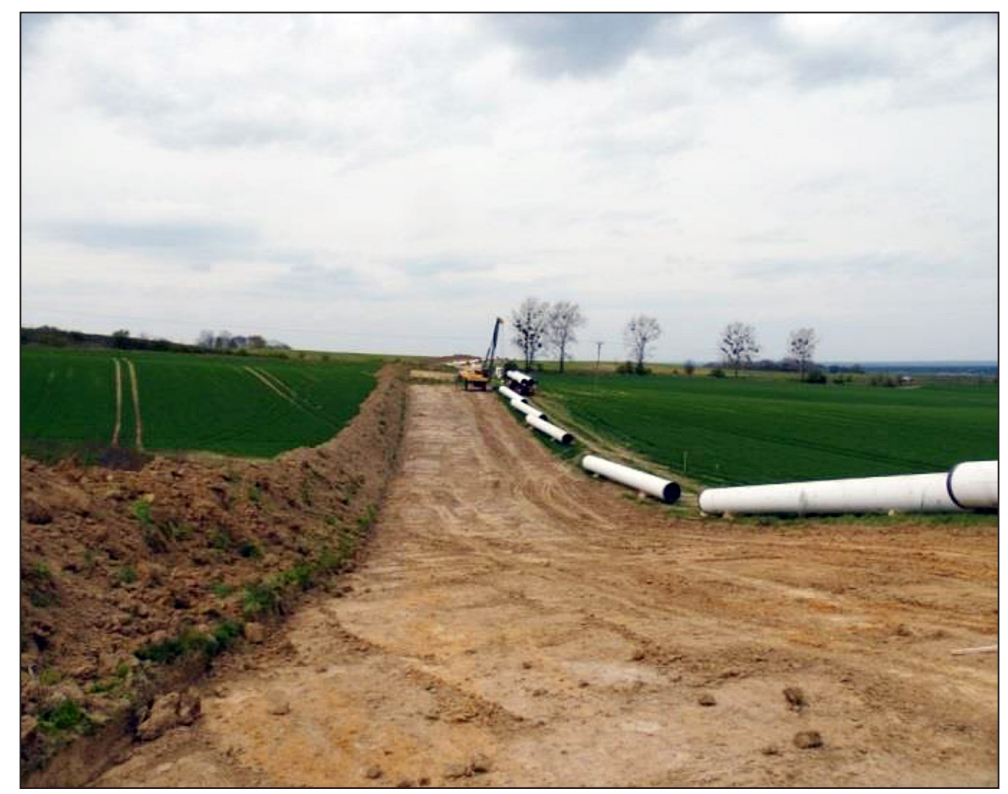

Figure 3. Image after the implementation of linear infrastructure

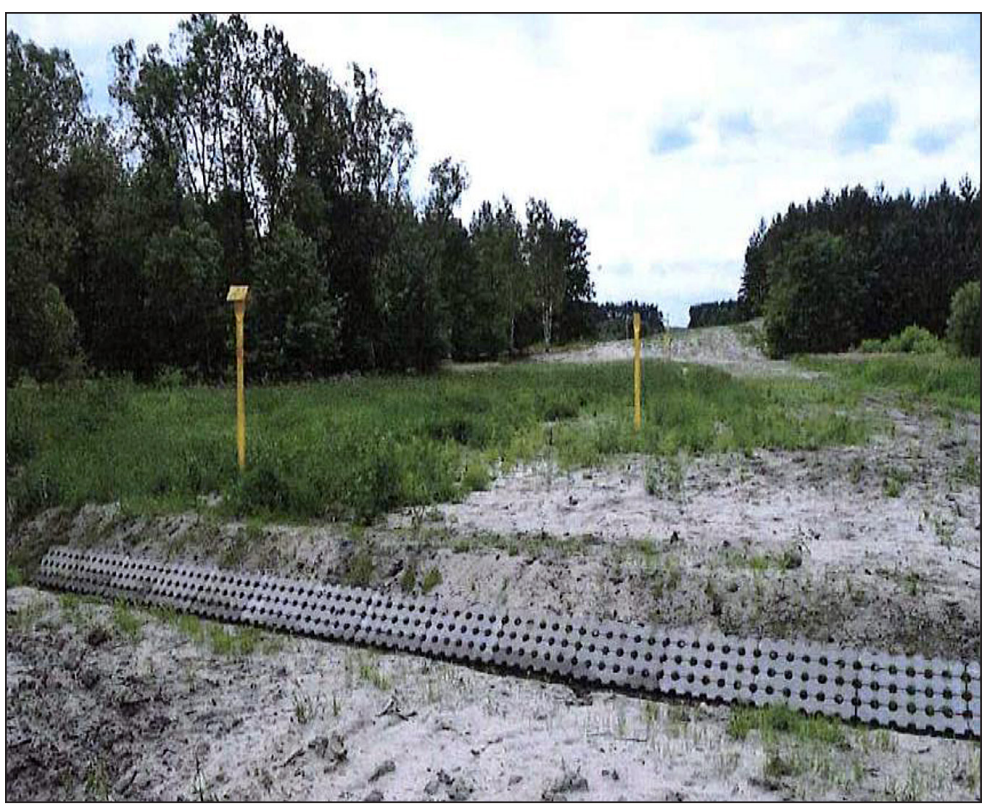

Figure 4. Image after the implementation of linear infrastructure 
If the natural gas is accidentally released and ignited, the hazard distance associated with these pipelines to people and property is known to range from under $20 \mathrm{~m}$ for a smaller pipeline at lower pressure, up to over $300 \mathrm{~m}$ for a larger one at higher pressure [Jo and Ahn, 2002; Jo and Crowl, 2008; Jo et al., 2004].

\section{CONCLUSIONS}

The conducted impact studies on the DN1000 gas pipeline allowed us to assess the actual impact of the investment on the individual components of the environment. It was found that particular nuisance was related to the process of the gas pipeline construction. The gas pipeline has a direct, negative medium or long-term impact on nearly all analyzed components of the environment. Many environmental changes are particularly acute, including e.g. - trees, pastures, meadows in forests and reduction of soil fertility due to soil damage.

During the operation period, particular nuisance was noted in forest and forest land and in forested areas, due to permanent and irreversible changes in the forest cover. With respect to most of the analyzed components, the impact of the gas pipeline is insignificant. However, it should be noted that the restrictions on the use of real estate caused by the network in relation to material goods. In the area of the controlled pipeline, there are permanent restrictions on the implementation of other functions than agricultural use. This limitation is permanent and there is a period of the gas pipeline operation. Further research into the issue of compensation should be undertaken as a permanent restriction on the use of real estate in connection with the implementation of a high pressure gas transmission network.

\section{REFERENCES}

1. Act of 16 April 2004 on nature conservation (Dz.U. z 2016 poz. 2134).

2. Brueckner, J., Fansler, D. (1983). The economics of urban sprawl: Theory and evidence on the spatial sizes of cities. Review of Economicsand Statistics, 55, 479-482.

3. Chi, CH.S.F., Ruuska, I., Xu, J. (2016). Environmental impact assessment of infrastructure projects: a governance perspective. Journal of Environmental Planning and Management, 59(3) 393-413.
4. Engel, Z. (2001). Ochrona środowiska przed drganiami i hałasem (2nd edition). Wydawnictwo Naukowe PWN, Warszawa.

5. Environmental impact report for the project (2014): Gazociąg wysokiego ciśnienia DN1000 MOP 8,4MPa na odcinkach od ZZU Czeszów do ZZU Wierzchowice oraz od ZZU Czeszów do węzła Kiełczów, TRACTEBEL ENGINEERING S.A., Katowice.

6. Guidelines for Landscape and Visual Impact Assessment. (2013). Third edition. The Landscape Institute with the Institute of Environmental Management and Assessment. Routledge Taylor \& Francis Group, New York.

7. Han, Z.Y., Weng, W.G. (2010). An integrated quantitative risk analysis method for natural gas pipeline network. J. Loss Prevent. Process Ind, 23(3), 428-436.

8. Hasheminasab, H., Gholipour, Y., Kharrazi, M., Streimikiene D. (2018). A novel metric of sustainability for petroleum refinery projects. Journal of Cleaner Production, 171,1215-1224.

9. Hasse, J., Lathrop, R.G. (2003). Land resource impact indicators of urban sprawl, Applied Geography, 23,159-175.

10. Hełdak, M., Raszka, B., (2011). Prognosis of the natural environment transformations resulting from spatial planning solutions. Polish Journal of Environmental Studies, 20(6) 1513-1518.

11. Jaffee, A., Suardina, A., Mcphate, JR. J (2009). Fire and explosion assessment on oil and gas floating production storage offloading (FPSO): an effective screening and comparison tool. Process Safety Environ. Protection, 87(3), 147-160.

12. Jawecki, B. (2017). Wizualna ocena roli czynnych kamieniołomów granitu w krajobrazie powiatu strzelińskiego (The visual evaluation of the role of working granite quarries in the landscape of Strzelin County). Prace Komisji Krajobrazu Kulturowego, 36, 79-97.

13. Jawecki, B., Lorenc, M.W., Tokarczyk-Dorociak, K., Wei, X. (2019). Reducing the environmental and landscape impacts of quarries using windbreaks and green-isolation zones. In: KrakowiakBal A., Vaverkova M. (eds) Infrastructure and Environment. Springer, Cham., 184-192, https://doi. org/10.1007/978-3-030-16542-0_25.

14. Jo, Y.-D., Ahn, B.J. (2002). Analysis of hazard area associated with highpressure natural-gas pipeline. Journal of Loss Prevention in the Process Industries, $15,179$.

15. Jo, Y.-D., Crowl D.A. (2008). Individual risk analysis of high-pressure natural gas pipeline, Journal of Loss Prevention in the Process Industries, 21(6), 589-595. 
16. Jo, Y.-D., Park, K.-S., Ahn, B.J. (2004). Risk assessment for a high-pressure natural gas pipeline in an urban area. The Sustainable City III, N. Marchettini, C. A. Brebbia, E. Tiezzi \& L. C. Wadhwa (Editors), WIT Press, www.witpress.com.

17. Joel, K., Duncan S. (2003). A practical approach to fire hazard analysis for offshore structures. J. Hazard. Mater., 104, 107-122.

18. Lowry, I. (1988). Planning for urban sprawl: Transportation Research Board Special Report, 220: 275312. Washington, DC: Transportation Research Board.

19. Ma, L., Cheng, L., Li, M. (2013). Quantitative risk analysis of urban natural gas pipeline networks using geographical information systems. Journal of Loss Prevention in the Process Industries, 26, 1183-1192.

20. Ma, L., Li, Y., Liang L., Li, M., Cheng, L. (2013). A novel method of quantitative risk assessment based on grid difference of pipeline sections. Safety Science, 59, 219-226.

21. Madungwe, E., Mukonzvi, T. (2012). Assessment of distribution and composition of quarry mine dust: case of Pomona stone quarries. Harare. Atmos. Clim. Sci. 2(1), 52-59.

22. Maziarek, A., Krawczyk A (2015). Gleba jako środowisko odżywcze roślin. Wydawnictwo Opolski Ośrodek Doradztwa Rolniczego, Opole.

23. Mazur, M. (2004). Air protection system. Wydawnictwo Naukowo-Dydaktyczne, AGH Kraków.

24. Morgan, R.K. (1998). Environmental impact assessment: a methodological perspective. Dordrecht: Kluwer Academic.

25. Morgan, R.K. (2012). Environmental impact assessment: the state of the art. Impact Assessment and Project Appraisal, 30(1), 5-14.
26. Ordinance of the Minister of the Environment of 6 October 2014 on the protection of species of animals (Dz.U. 2016 poz. 2183)

27. Rak, A. (2014). Budowlane przedsięwzięcia inwestycyjne. Środowiskowe uwarunkowania przygotowania i realizacji. [Construction investment projects. Environmental conditions of preparation and implementation] Wydawnictwo Naukowe PWN, Warszawa.

28. Sas-Bojarska, A. (2007). Prediction of landscape changes in land use management, using environmental impact assessment with the example of roads. Przedsiębiorstwo Prywatne WIB, Gdańsk.

29. Shen, L., Wu, Y., Zhang, X. (2011). Key assessment indicators for the sustainability of infrastructure projects. Journal of Construction Engineering and Management, 137(6), 441-451, https://doi. org/10.1061/(ASCE)CO.1943-7862.0000315.

30. Sklavounos, S., Rigas F. (2006). Estimation of safety distances in the vicinity of fuel gas. J. Loss Prevent. Process Ind, 19, 24-31.

31. Smaga, S., Włudyka, T (2012). Market economy institutions. Wydawnictwo Wolters Kluwer, Warszawa.

32. Suchocka, M., Milanowska A. (2015). Greenery, Structural substrates and conflicts between trees and infrastructure. Wydawnictwo ABRYS sp. z o.o.

33. Świąder, M. Szewrański, Sz., Kazak, J. (2016). Spatial - Temporal Diversification of Poverty in Wroclaw, World Multidisciplinary Civil Engineering-Architecture-Urban Planning Symposium 2016, WMCAUS Praga 2016, Procedia Engineering 161, 1596-1600.

34. Tokarczyk-Dorociak, K., Kazak, J.K., Haładyj, A., Szewrański,Sz., Świąder, M. (2019). Effectiveness of strategic environmental assessment in Poland. Impact Assessment and Project Appraisal, 37(3-4), 279-291, DOI: 10.1080/14615517.2019.1601441 